\title{
Harvest Management of Tundra Swans Cygnus columbianus in North America
}

\author{
JEROME R. SERIE and JAMES C. \\ BARTONEK
}

Sport hunting of Tundra Swans in the U.S. is regulated under provisions of the Migratory Bird Treaty Act of 1918. Management plans cooperatively developed and agreed to between Flyway Councils and Federal wildlife agencies in Canada and the U.S. prescribe allowable harvest levels and provisions for regulating it. Harvests are managed by Eastern and Western Populations. Presently, hunts are authorized in specific locations during fall migration in the States of Alaska, Montana, Nevada, North and South Dakota, and Utah and on wintering areas in the States of New Jersey, North Carolina, and Virginia. A specified number of permits are approved by the USFWS to participating states allowing each applicant to take one Tundra Swan per season. During 1979. 88 , the number of permits to harvest Western Population swans has averaged 3,552 per year. Of these, 1,075 swans are retrieved and 215 unretrieved. During 1986-88, an average of 6,467 permits have been issued to harvest Eastern Population swans. Of these, an average of 2,617 swans are retrieved and 302 unretrieved. In recent years, about 10,000 permits are issued and account for a total kill of about 4,200 annually, including retrieved and unretrieved. Of this amount, 70\% are derived from the Eastern Population and $30 \%$ results from the Western Population. These harvest estimates account for less than $3 \%$ of the pre-season winter population estimate and are below the $10 \%$ harvest rate guideline specified in the management plans. Both Eastern and Western Populations of Tundra Swans have increased in numbers and expanded their distributions over the years since special hunting seasons were first established. Presently, these numbers exceed the populations goals prescribed by various management plans. To better assess the effects of hunting on Tundra Swans, special studies are needed to validate population estimates, identify subpopulations, determine seasonal movements and measure changes in recovery and survival rates.

Sport hunting of Tundra Swans Cygnus columbianus columbianus in the United States (U.S.) and Canada is provided for under provisions on the Migratory Bird Treaty of 1916. As implemented in the U.S. by the Migratory Bird Treaty Act of 1918, all ducks, geese and swans in the family Anatidae are identified as migratory game birds and entrusted to the Federal government to regulate their take, possession, transportation and sale. Although swans were hunted prior to the treaty and a strong tradition of hunting swans existed in the U.S., the legal harvest of Tundra Swans was not again permitted by Federal regulations until 1962 when a season was authorized in Utah. Numbers of Tundra Swans had increased steadily over the years since early surveys in the late 1930 s (Bartonek et al. 1981) and had reached satisfactory levels to warrant a limited harvest. Since the 1950s, the number of Tundra Swans in North America has more than doubled and both
Eastern (EP) and Western (WP) populations have shown similar long term increases of about $2 \%$ annually (Serie \& Bartonek 1991).

In 1984, the U.S. Fish and Wildlife Service (USFWS) considered if hunting was an appropriate tool for managing EP Tundra Swans in the Atlantic Flyway. In the Environmental Assessment "Proposed Hunting Regulations on Eastern Population of Tundra Swans, 1984" (USDI 1984), the USFWS concluded that hunting of EP Swans was biologically justified based on numbers of swans occurring in specific habitats during migration and winter. Sport hunting of Tundra Swans is presently authorized in specific locations during fall migration in the States of Alaska, Montana, Nevada, North and South Dakota, and Utah and on wintering areas in the States of New Jersey, North Carolina, and Virginia. The initiation of these seasons marks a new era of swan hunting opportunities and brings new challenges for managing populations 
of Tundra Swans into the future.

The hunting of EP and WP Tundra Swans is managed by guidelines cooperatively developed and agreed upon between Flyway Councils, which consist of States and Provinces, and Federal wildlife agencies in Canada and the United States. Sport hunting plans for both the EP and WP prescribe levels of allowable harvest and provisions for regulating it. These hunt plans are axillar to the EP and WP management plans (Ad Hoc Whistling Swan Committee 1982, Schroeder 1983) which prescribe desired population levels, distribution patterns, and habitat requirements to be maintained to provide maximum benefit to society, including aesthetic, education, scientific, and hunting purposes. A goal for the EP is to stabilize the population within a range of between 60,000 and 80,000 swans, based on a three-year average winter population index; and the WP is to be maintained at a level above 38,000 swans. Both management plans are subject to periodic review and revision as appropriate. Population goals identified in the North America Waterfowl Management Plan (CWS \& USFWS 1986) are to maintain numerical levels of 80,000 and 60,000 for EP and WP, respectively, until the year 2000 .

This paper reviews guidelines of the two sport hunting plans, including harvest objectives, prerequisites for hunts, allocation and regulation of harvests, procedures for evaluating impacts, and potential risks to other protected species such as Trumpeter Swans Cygnus buccinator.

\section{Methods}

\section{General Guidelines}

Proposals to harvest Tundra Swans are developed by State wildlife agencies based on considerations of population status and public interest and submitted to the appropriate Flyway Councils for their endorsement. Proposals are judged on biological merit, general guidelines detailed in the EP and WP hunt plans, and agency's capability for monitoring the harvest and possible changes in population size and distribution. Recommendations regarding the establishment or continuance of a season, either for or against, are received by the USFWS from the Flyway Councils, individual States, organizations and the general public during the annual process of promulgating regulations permitting the sport harvest of migratory game birds. If authorized, swan seasons are designated as being "experimental" for at least three years before "operational" status is considered; however, all seasons are subject to annual review and possible modification or deletion. Seasons vary in length by Flyway, ranging from 60 to 93 days; and in Atlantic and Pacific Flyways, they must run concurrently with those for snow geese.

A special, non-transferable permit allowing the taking of one Tundra Swan per season is issued by the State agency to successful applicants. Costs associated and methods of distributing these permits are the prerogatives of each State Agency. Immediately upon taking a swan, the harvest must be validated according to whatever method is customary for that State and acceptable to the USFWS. Typically, validation involves affixing either a locking, metal tag or seal around the base of the wing or a nonreusable paper tag around the neck or tarsus, the date and location of the harvest are recorded on the pernit, and the permittee signs the permit certifying the harvest. Permittees are required to complete a questionnaire to assess: (1) number of sport hunting days, (2) if a swan was harvested, (3) whether the head or neck plumage was white or grey, and (4) how many swans were knocked down but not retrieved. The hunter is either mailed a follow-up questionnaire or telephoned if the initial questionnaire was not received. Data are then compiled by the agencies and reported to the USFWS and Flyway Councils each year prior to the development of annual hunting regulations.

Any State or Province conducting a season must agree to monitor the size and age composition of the population and the timing of migration or wintering use by swans in the hunt area. Adjustments to the number of permits allowed are reviewed during the annual regulation development cycle.

\section{Harvest Strategies}

Harvest objectives for both EP and WP hunt plans are to annually harvest the optimum allowable number of swans and still maintain populations at satisfactory levels to meet goals of the various management plans. Without specific information on annual survival and recruitment rates, it is difficult to establish with precision a maximum allowable harvest rate each year. Therefore, to avoid yearly adjustments, a $10 \%$ harvest rate of the three-year average winter population index has been established as a guide until more definitive data are available. This allowable harvest objective 
includes an estimated $20 \%$ crippling or unretrieved loss. Subsistence harvest is assumed to be stable at current levels but can be factored in where information exits. If the three-year average winter population index for EP and WP Swans falls below 60,000 and 40,000 , respectively, season closures will be considered. These harvest strategies are subject to periodic review and revision as needed to meet prescribed population objectives set by the various management plans.

The number of permits issued al ways exceeds the allowable harvest because not all hunters are successful. For the WP, where there is longterm data, a $31 \%$ success rate is used to calculate the number of permits issued; but for the EP, a conservative $50 \%$ success rate is used until more experience has been gained.

\section{Permit Allocations}

Permits are apportioned among all regions frequented by both EP and WP swans to equitably distribute hunting opportunities rather than considering only those areas where Tundra
Swans are most numerous. Thus, the allowable harvest for an entire population is divided somewhat arbitrarily among seasonal ranges. For example, permits to harvest EP swans are distributed on the following bases: production areas $33 \%$, migration areas $33 \%$, and wintering areas $34 \%$. For WP swans, production areas receive $10 \%$ of the total permits available; migration areas, $70 \%$; and wintering areas, $20 \%$. These percentages are based generally on tradition of harvest, subsistence use, number of States/Provinces potentially sharing permits, access or interest in swan hunting and opportunities to harvest swans. More opportunity exists to harvest swans on migration and wintering areas than on production areas where subsistence harvest has been more traditional.

Any unused allocation of permits is available for redistribution to other regions; but, if a State in that region requests a season, these permits must go back to the area in which they were originally assigned. When this occurs, the number of permits available for redistribution must be recalculated. Any change in the number and distribution of permits must be reviewed by

Table 1. Seasonal length, number of permits, hunter activity, retrieved and unretrieved harvests and percentage of young in bags during combined seasons on WP Tundra Swans, 1962-1988.

\begin{tabular}{|c|c|c|c|c|c|c|c|}
\hline Year & $\begin{array}{l}\text { Season* } \\
\text { Length }\end{array}$ & $\begin{array}{l}\text { Number of } \\
\text { Pemits } \\
\text { Issued }\end{array}$ & $\begin{array}{l}\text { Per cent } \\
\text { Hunting }\end{array}$ & $\begin{array}{c}\text { Estimated } \\
\text { Number of } \\
\text { Hunter days }\end{array}$ & $\begin{array}{c}\text { Estimated } \\
\text { Retrieved } \\
\text { Harvest }\end{array}$ & $\begin{array}{l}\text { Estimated } \\
\text { Number } \\
\text { Unretrieved }\end{array}$ & $\begin{array}{c}\text { Average } \\
\text { Per cent } \\
\text { of Young** }\end{array}$ \\
\hline 1962 & 68 & 1000 & $0.0 \%$ & 0 & 320 & 81 & 38 \\
\hline 1963 & 90 & 1000 & $0.0 \%$ & 0 & 392 & 62 & 48 \\
\hline 1964 & 90 & 1000 & $94.0 \%$ & 4600 & 335 & 86 & 37 \\
\hline 1965 & 90 & 995 & $92.0 \%$ & 4700 & 336 & 60 & 45 \\
\hline 1966 & 90 & 1000 & $95.5 \%$ & 4000 & 491 & 75 & 42 \\
\hline 1967 & 90 & 1000 & $91.0 \%$ & 4800 & 246 & 69 & 54 \\
\hline 1968 & 86 & 1000 & $93.0 \%$ & 4300 & 520 & 102 & 58 \\
\hline 1969 & 86 & 3000 & $74.2 \%$ & 11410 & 1377 & 266 & 63 \\
\hline 1970 & 93 & 3500 & $70.7 \%$ & 14100 & 1199 & 170 & 47 \\
\hline 1971 & 93 & 3495 & $80.3 \%$ & 13670 & 1109 & 175 & 34 \\
\hline 1972 & 93 & 3500 & $79.0 \%$ & 13854 & 1028 & 118 & 34 \\
\hline 1973 & 93 & 3500 & $79.4 \%$ & 11605 & 1191 & 257 & 47 \\
\hline 1974 & 93 & 3500 & $83.9 \%$ & 13977 & 1377 & 298 & 43 \\
\hline 1975 & 93 & 3500 & $83.3 \%$ & 13069 & 1383 & 241 & 39 \\
\hline 1976 & 93 & 3500 & $83.9 \%$ & 12032 & 1109 & 164 & 39 \\
\hline 1977 & 93 & 3488 & $75.8 \%$ & 9737 & 1575 & 347 & 45 \\
\hline 1978 & 93 & 3500 & $81.9 \%$ & 10613 & 1152 & 375 & 43 \\
\hline 1979 & 93 & 3500 & $83.6 \%$ & 11551 & 1293 & 345 & 36 \\
\hline 1980 & 93 & 3500 & $82.7 \%$ & 10950 & 1156 & 223 & 41 \\
\hline 1981 & 93 & 3500 & $85.7 \%$ & 10756 & 1619 & 377 & 33 \\
\hline 1982 & 93 & 3500 & $84.0 \%$ & 12743 & 1244 & 311 & 29 \\
\hline 1983 & 93 & 3650 & $82.4 \%$ & 12452 & 1168 & 286 & 39 \\
\hline 1984 & 93 & 3650 & $80.7 \%$ & 13037 & 1194 & 126 & 33 \\
\hline 1985 & 93 & 3645 & $74.9 \%$ & 13527 & 673 & 97 & 31 \\
\hline 1986 & 93 & 3608 & $78.3 \%$ & 12884 & 947 & 185 & 34 \\
\hline 1987 & 93 & 3593 & $75.8 \%$ & 13519 & 600 & 66 & 34 \\
\hline 1988 & 93 & 3372 & $74.0 \%$ & 9656 & 854 & 123 & 33 \\
\hline \multicolumn{2}{|c|}{ AVERAGE } & 2852 & $78.6 \%$ & 9909 & 959 & 188 & $4 !$ \\
\hline
\end{tabular}

*Maximum days

**Unweighted 
Table 2. Average number of permits issued, retrieved and unretrieved harvests and percentage of young in bags during WP Tundra Swan seasons by State 1979-88.

\begin{tabular}{lcccc}
\hline & $\begin{array}{c}\text { Number of } \\
\text { permits } \\
\text { issued }\end{array}$ & $\begin{array}{c}\text { Estimated } \\
\text { Retrieved } \\
\text { Harvest }\end{array}$ & $\begin{array}{c}\text { Estimated } \\
\text { Number } \\
\text { Unretrieved }\end{array}$ & $\begin{array}{c}\text { Per cent } \\
\text { Young }\end{array}$ \\
Utak & 2,500 & $684(27)^{\star}$ & 168 & 41 \\
Nevada & 541 & $169(31)^{\star}$ & 26 & 33 \\
Western Montana & 500 & $221(44)^{\star}$ & 20 & 30 \\
Aiaska** & 112 & $15(13)^{*}$ & 0 & 75 \\
\hline
\end{tabular}

* Success rate in parentheses

$\star * 1988-89$ Season only in Alaska

** Unweighted

the appropriate Flyway Council and approved by the USFWS.

\section{Results}

\section{WP Harvest Program}

Season length, number of permits issued, hunter participation, and harvest data on WP Tundra Swans are presented in Table 1 . The first season was held statewide in Utah in 1962. In 1969, Nevada was permitted a season in Churchill County, and Lyon and Pershing Counties were added in 1983. The Pacific Flyway portion of Montana was authorized a season in Teton County in 1970, and in Cascade County in 1981, and in Toole, Liberty, Hill and Pondera Counties in 1988. Alaska had its first season on WP Tundra Swans in 1988 on the Seward Peninsula. Swan hunting in Nevada, Montana, and Alaska has been limited to designated areas to reduce the risk of killing Trumpeter Swans.

The number of permits authorized to harvest WP Tundra Swans have been 1,000 during $1962-68,3,000$ in $1969,3,500$ during $1970-82$, 3,650 during $1983-87$ and 3,950 in 1988 . During the 1988-89 season, the allocation of permits was 2,500 to Utah, 650 to Nevada, 500 to
Montana and 300 to Alaska. Interest in swan hunting has been high in Western States; and, except for a few areas, exceeds the number of permits available. An estimated $74 \%$ of the permittees reported hunting in 1988 and accounted for nearly 10,000 hunter-days in the pursuit of swans.

The estimated yearly number of WP Swans retrieved and unretrieved has varied as the number of permits issued and success rates have changed. In the 27-year history of hunting WP Tundra Swans, an average of 959 swans were retrieved while 188 went unretrieved (Table 1). The average retrieved and unretrieved harvests are shown in Table 2 . The percentage of cygnets or "grey plumaged" birds in the retrieved harvests varies considerably, but has averaged $38 \%$ yearly. The proportion of young in bags was considerably higher in Alaska than in Utah, Nevada and parts of Montana. At present, Utah harvested $64 \%$ of the WP, followed in importance by Nevada $16 \%$, Montana $20 \%$, and Alaska $1 \%$. Hunter-success rates were highest in Montana (60\%) and lowest in Alaska (24\%).

\section{EP Harvest Program}

Season length, number of permits issued, hunter participation, and harvest data on EP Tundra

Table 3. Season length, number of permits, hunter activity, retrieved and unretrieved harvests and Percentage of young in bags during combined seasons on EP Tundra Swans, 1983-88.

\begin{tabular}{lccccccc}
\hline Year & $\begin{array}{c}\text { Season* } \\
\text { Length }\end{array}$ & $\begin{array}{c}\text { Number of } \\
\text { Permits } \\
\text { Issued }\end{array}$ & $\begin{array}{c}\text { Per cent } \\
\text { Hunting }\end{array}$ & $\begin{array}{c}\text { Estimated } \\
\text { Number of } \\
\text { Hunter days }\end{array}$ & $\begin{array}{c}\text { Estimated } \\
\text { Retrieved } \\
\text { Harvest }\end{array}$ & $\begin{array}{c}\text { Estimated } \\
\text { Number } \\
\text { Unretrieved }\end{array}$ & $\begin{array}{c}\text { Average } \\
\text { Per cent } \\
\text { of Young }\end{array}$ \\
\hline 1983 & 93 & 109 & $64.0 \%$ & 169 & 34 & 0 & 26 \\
1984 & 93 & 1108 & $38.7 \%$ & 2934 & 335 & 22 & 31 \\
1985 & 93 & 6120 & $74.7 \%$ & 15345 & 2551 & 260 & 26 \\
1986 & 93 & 6170 & $71.2 \%$ & 14915 & 2343 & 277 & 28 \\
1987 & 93 & 6139 & $78.4 \%$ & 14313 & 2711 & 324 & 21 \\
1988 & 93 & 7094 & $71.0 \%$ & 15344 & 2797 & 305 & 32 \\
Average & & 4457 & $72.2 \%$ & & 1795 & 198 & 27 \\
\hline
\end{tabular}

*Maximum days

** Unweighted 
Table 4. Average number of permits issued, retrieved and unretrieved harvests and percentage of young in bags during EP Tundra Swan seasons by State 1986-88.

\begin{tabular}{lcccc}
\hline State & $\begin{array}{c}\text { Number of } \\
\text { permits } \\
\text { issued }\end{array}$ & $\begin{array}{c}\text { Estimated } \\
\text { Retrieved } \\
\text { Harvest }\end{array}$ & $\begin{array}{c}\text { Estimated } \\
\text { Number } \\
\text { Unretrieved }\end{array}$ & $\begin{array}{c}\text { Per cent } \\
\text { Young }\end{array}$ \\
\hline Eastem Montana & 147 & $31(21)^{\star}$ & 0 & 41 \\
North Carolina & 5,988 & $2,485(41)^{\star}$ & 290 & 20 \\
North Dakota & 400 & $187(47)^{\star}$ & 25 & 17 \\
Virginia $\star *$ & 600 & $117(20)^{\star}$ & 9 & 26 \\
\hline
\end{tabular}

* Success rate in parenthesis

** 1988-89 season only in North Dakota and Virginia $\star \star \star$ Unweighted

Swans are shown in Table 3. In 1983, the Central Flyway portion of Montana was the first to have a season on EP Tundra Swans. While both North Dakota and South Dakota were also authorized seasons in 1983, they both declined the hunts; and it was not until 1988, that North Dakota chose to exercise this option. In 1984, North Carolina became the first State in the Atlantic Flyway to be granted an experimental season. Experimental seasons were approved for Virginia and New Jersey in 1988, but only Virginia elected to have a swan hunt.

The number of permits available to harvest EP Swans was limited to 109 in 1983 and increased to 1,108 in 1984 . In 1985 , the number of permits authorized to North Carolina was increased from 1,000 to 6,000 and the total number of EP swan permits rose to 6,120 , to 6,170 in 1986 and to 7,094 in 1988. During the 1988-89 season, Montana received 99 permits, North Carolina 6,000, North Dakota 1,000(but issued only 400), and Virginia 600 . South $\mathrm{Da}-$ kota has been approved to issue 500 permits and New Jersey 200 permits if they should decide to offer a season. An estimated $71 \%$ of permittees hunted during the 1988-89 seasons and spent more than 15,000 hunter-days in the field.

During the brief six-year history of hunting
EP Tundra Swans, the estimated annual retrieved and unretrieved kill has averaged 1,795 and 198 swans, respectively (Table 4). During 1986-88, the average estimated numbers retrieved and unretrieved are shown in Table 4. Over this same time, hunter success averaged $40 \%$ and the percentage of young bagged averaged $26 \%$. During the most recent three-year period (only 1988-89 season for North Dakota and Virginia), North Carolina accounted for $88 \%$ of the EP harvest, followed by North Dakota (7\%), Virginia (4\%), and Montana (1\%) (Table 4 ). Hunter-success rates are difficult to compare for North Dakota and Virginia since data are limited to a single season; however, hunter success appears to be higher in North Carolina on wintering grounds than in Montana during migration. Also, hunter success seems to be highest early in the season than later when swans are more wary. Unretrieved losses approximate $10 \%$ of the total harvest and seem to be similar among harvest areas.

\section{Total Harvests}

The number of permits issued and the average combined annual harvest of EP and WP Tundra Swans are shown in Table 5. These estimates

Table 5. Average number of permits issued, retrieved and unretrieved harvests and percentage of young in bags during EP and WP Tundra Swan seasons in North America.

\begin{tabular}{lcccc}
\hline State & $\begin{array}{c}\text { Number of } \\
\text { permits } \\
\text { issued }\end{array}$ & $\begin{array}{c}\text { Retrieved } \\
\text { Harvest }\end{array}$ & $\begin{array}{c}\text { Number } \\
\text { Unretrieved }\end{array}$ & $\begin{array}{c}\text { Total } \\
\text { Kill }\end{array}$ \\
\hline $\begin{array}{l}\text { Eastern } \\
\text { Population** }\end{array}$ & 6,467 & $2,617(40)^{\star}$ & 302 & 2,919 \\
$\begin{array}{l}\text { Western } \\
\text { Population }\end{array}$ & 3,552 & $1,075(30)^{\star}$ & 215 & 1,290 \\
Total & 10,019 & $3,692(37)^{\star}$ & 517 & 4,209 \\
\hline
\end{tabular}

* Success rate in parenthesis

**3-Year average

$* * * 10-$ Year average 
indicate that in recent years about 10,000 permits are issued and 3,692 swans are retrieved and 517 unretrieved for a total average kill of about 4,209 each year. Of this amount, $70 \%$ are derived from the EP while $30 \%$ occur from the WP. Crippling or unretrieved losses account for an estimated $12 \%$ of the total harvest. An estimated $70 \%$ of permittees hunted and spent more than 25,000 hunter-days in the field during the 1988-89 season. Hunter success was estimated to be higher on EP than on WP Swans.

\section{Discussion:}

\section{Evaluations of Hunting Programs}

Population indices from the Midwinter Waterfowl Surveys in January (Serie \& Bartonek 1991) and from periodic surveys conducted in the hunt areas are used to evaluate impacts from hunting programs. The 1987-89, three-yearaverage, winter population index for EP and WP Tundra Swans is 87,065 and 63,751 , respectively, which exceed objective levels of 80,000 and 60,000 in the North American Waterfowl Management Plan (CWS \& USFWS 1986) and 60,000-80,000 and 38,000, in EP and WP Tundra Swan Management Plans (Ad Hoc Whistling Swan Committee 1982, Schroeder 1983), respectively. Actually, the average annual rate of increase in WP swans was significantly greater $(\mathrm{t}=-7.076, P<0.00 \mathrm{I})$ after the initiation of swan hunting seasons in 1962-89, than for the period $1955-61$, prior to any sport hunting. Since 1980, winter population indices for WP swans seem to be declining; however, little change can be detected from the long-term trends due to the extreme variability of these data. Breeding survey indices of the WP in Alaska (Conant et al. 1991) show no evidence of a decline in breeding populations.

In North Carolina, Midwinter Waterfowl Surveys show that EP Tundra Swans have increased by about 12,000 birds or $30 \%$ from the 1980-84 average during the pre-hunt period to the 1985-89 average during the post-hunt period. While population comparisons are yet limited in other areas where EP swans are hunted, population trends during 1980-89 continue to increase at a pace which exceeds the 1955-89 long-term trend (Serie \& Bartonek 1991). Although hunting of EP swans is much more recent than on WP swans, there is little direct evidence that hunting has had any significant negative impact on their numbers. Without more banding and marking data to substantiate changes in survival rates, measurable impacts on the population status of Tundra Swans resulting from harvest programs will be difficult to fully assess.

Total harvests of Tundra Swans, (including retrieved and unretrieved kill) resulting from special seasons have been considerably below the $10 \%$ guidelines in the EP and WP hunt plans. Currently, these harvest estimates account for about $3 \%$ and $2 \%$, respectively, of the 1987 89 average winter population indices for EP and WP Tundra Swans. Thus, less than $3 \%$ of the continental preseason population of Tundra Swans is harvested each year. While these harvest rates are low, the hunt plans assume hunting mortality to be additive, and therefore, must be considered along with other mortality factors (Bartonek et al. 1991). The lack of precise estimates of subsistence harvests, vandalized killing, and losses annually to disease, lead poisoning, and accidental death, complicates any attempt to calculate more meaningful harvest rates. Therefore, the current hunt plans for EP and WP Tundra Swans must remain conservative in their approach to harvest optimum allowable numbers until refinements in our database can be made.

\section{An Assessment of Swan Hunting}

Prior to the mid-1800's, many observers reported swans to be relatively numerous (Banko 1960); but subsequent over-harvesting was suspected as being a major factor in the declines of both Tundra and Trumpeter Swans, with some populations of Trumpeter Swans being extirpated and others nearly so. Both Banko (1960) and Forbush (1912) give extensive accounts of the demise of swans at the hand of man. Between 1853 and 1877 , more than 17,671 swan skins were reported sold to the Hudson Bay Company and by 1889 , the number had dwindled to just 33 as swan numbers declined. While early sportsman regarded swans as worthy quarry and often made note of their shooting experiences, the combined seasonal killing of swans by natives and non-natives for food, market, or sport likely exceeded recruitment annually. With the Migratory Bird Treaty Act of 1918 , both species of swans received the much-need nation-wide protection but, nonetheless, retained their status as "game birds."

Interest in the sport hunting of Tundra Swans has changed over the years as their numbers have increased and as some populations have become locally abundant. Before the initiation of the first regulated season in Utah, Sherwood 
(1960) reported that wildlife agencies in most western States were opposed to hunting swans. $\mathrm{He}$ feared that with hunting, swan numbers would not continue to grow in North America and that due to their relative size, crippling losses would be high. Also, he expressed concern that such hunting would unduly jeopardize the restoration of Trumpeter Swan populations and, further, would conflict with the aesthetic values society has assigned to swans. Although his concerns and those of many others at that time were understandable, the eventuality of swan seasons in western States and the newly acquired information gathered from seasons in eastern States do not support most fears.

Both EP and WP Tundra Swans have increased in numbers and expanded their distributions over the years since special hunting seasons were first established. Estimates of unretrieved losses have ranged from $10 \%$ to $17 \%$ and averaged near $12 \%$, which is lower than the estimated $18 \%$ for other waterfowl. These estimates were obtained from hunter questionnaires and may contain some bias. Obviously, hunting methods used to harvest swans vary regionally based on the season, hunter access and habits of the birds and likely have an effect on the incidence of crippling. Montana, for example, requires swan hunters to use either a dog, boat or chest wader when hunting swans in certain areas to facilitate retrieval. Swans are strong flyers and perhaps can carry more shot than other waterfowl, and as a result, fears of crippling may be valid, particularly if it increases risks of other mortality. Also, given the fact that these large white birds are easily observed, extensive crippling may elicit strong public reaction. More study of hunting methods, shot-shell effectiveness and killing efficiency in areas where swans are hunted should be encouraged. This information would be extremely helpful in developing future harvest guidelines.

Potential conflicts of Tundra Swan hunting programs with efforts to restore Trumpeter Swans numbers exist in certain locations, particularly on breeding grounds and during migration. The problem is more acute with WP than with EP swans, although with Trumpeter Swan restoration efforts in the Midwest this situation could change. Both EP and WP Tundra Swan management plans, including hunt plans, and the Trumpeter Swan management plan recognize that potential for conflict exists and acknowledge that incidental harvests of Trumpeter Swans will likely occur during these seasons as with some goose seasons. Such losses would likely occur regardless of Tundra Swan seasons as Trumpeter Swan numbers increase and their distribution expands. All plans seek reconciliation of conflicting management activities. As clarified in a recent policy, the USFWS intends to avoid the hunting of swans at times or in places where Trumpeter Swans are known to occur and has urged Flyway Councils to give strong consideration to finding ways of avoiding the chance-killing of Trumpeter Swans when Tundra Swan seasons are proposed. At present, there is no evidence to suggest that efforts to restore Trumpeter Swans have been impeded by hunting of Tundra Swans; however, the USFWS has indicated that it will deal with such conflicts on a case-by-case basis as they arise.

Swans are aesthetically valued by the public for viewing and photographing as are many other species of waterfowl. As large birds, they attract considerable attention, especially when in large migrating flocks and in concentrations near urban centers. As a game species, they evoke strong emotion and considerable public sentiment exists regarding the hunting of swans. Those opposed to the hunting of swans feel that swans are too beautiful and symbolic to warrant hunting. Those favoring a season believe numbers of Tundra Swans are adequate to biologically justify a limited harvest in specific areas to stabilize population size and still meet the other demands of society. While these diverse views were considered in detail during the preparation of the environmental assessment that preceded EP swans being hunted (USDI 1984), the decision to authorize these seasons was based primarily on their population status and only secondarily on possibilities for recreational opportunities. Since swans were among those species hunted prior to 1918 , a tradition did exist in many areas for harvesting swans. Many waterfowl hunters regard Tundra Swans as a trophy game species and place high value on the opportunity to hunt them.

In some localized areas of the Atlantic Flyway, swans winter in large concentrations and cause damage to agricultural crops by feeding in fields (Munro 1981). Although this recently acquired feeding behaviour is thought to have considerable nutrition value (Bortner 1985) and may enhance seasonal survival, monetary losses have created local opposition to the presence of the birds. In North Carolina, some farmers have resorted to shooting swans illegally in an attempt to disperse them from their fields (D. C. Luszcz, pers. comm.). In these isolated instances, swan hunting to allow a limited harvest by special 
permit has helped to alleviate local problems. However, in most portions of their range, Tundra Swans pose few social or economic problems.

In conclusion, the status of EP and WP Tundra Swans appears to be adequate at the present time to provide maximum benefits to society, which includes continuance of a limited hunting program. As long as populations remain above objective numbers and special hunts are conducted in accordance with the guidelines established in each of the hunt plans, a limited harvest seems biologically justifiable. Banding and marking studies are needed for both EP and WP swans to validate population estimates, assess seasonal movements and site fidelity, and document recovery and survival rates.
Answers to these questions are of particular importance since swans have considerable aesthetic value, are long lived, and have low recruitment. Expansion of harvests beyond existing levels will likely be limited in the years ahead. Possibly, the Northwest Territories may seek a season and South Dakota may avail itself of its authorized season, but other States and Provinces likely will not seek a season for various reasons. Overall, it will be the responsibility of the Federal and State/Provinces wildlife agencies and Flyway Councils to monitor populations and their distributions carefully and to modify these hunt plans where necessary to ensure that adequate numbers remain for future generations to enjoy.

We wish to thank T. W. Aldrich, Utah Division of Wildlife Resources, J. Herbert, Montana Department of Fish. Wildlife and Parks, T. Retterer, Nevada Department of Wildlife, T. Rothe, Alaska Fish and Game, M. A. Johnson, North Dakota Game and Fish Department, and D. C. Luszcz, North Carolina Wildlife Resources Commission, for providing annual harvest data and evaluation reports from each of the participating States. We acknowledge the efforts of the many State and Federal biologist who participated in the development and the implementation of the EP and WP Tundra Swan Hunt Plans. We are grateful A. Davenport for technical assistance on data presentation and we thank L. A. Pickard for preparing tables and typing portions of this manuscript. We appreciate the editorial assistance of R. J. Blohm, K. E. Gamble, W. N. Ladd, and M. M. Smith on various drafts of this manuscript.

\section{References}

Ad Hoc Whistling Swan Committee. 1982. Management plan for the eastern population of Whistling Swans. [Atlantic Flyway Council, Mississippi Flyway Council, Central Flyway Council, and Pacific Flyway Council.] Unpubl. Rept. 23 pp.

Banko, W. E. 1960. The Trumpeter Swan: its history, habits and population in the United States. North Am. Fauna 63. U. S. Fish and Wildl. Serv., Washington D. C. 214pp.

Bartonek, J.C., Serie, J.R. \& Converse, K.A. 1991 . Mortality in Tundra Swans, Cygnus columbianus. In: J. Sears \& P.J. Bacon (eds.). Proc. 3rd Int. Swan Symp., Oxford, 1989. Wildfowl (Special Supplement no.1).

Bartonek, J. C., Blandin, W. W., Gamble, K. E., and Miller, H. W. 1981. Numbers of swans wintering in the United States. Pp. 19-25 In: G. V. T. Matthews, \& M. Smart, (eds.), Proc. 2nd Int. Swan Symp., Sapporo, 1980. IWRB, Slimbridge.

Bortner, J. B. 1985. Bioenergetics of wintering Tundra Swans in the Mattamuskeet Region of North Carolina. Univ. of Maryland, M. S. Thesis. 64pp.

Canadian Wildlife Service \& U. S. Fish and Wildlife Service. 1986. North American waterfowl management plan. The agencies, Ottawa and Washington, D.C. 19 pp.

Conant, B., Hodges, J.I. \& King, J.G.. 1991. Continuity and advancement of Trumpeter Swan Cygnus buccinator, and Tundra Swan, C. columbianus, population monitoring in Alaska. In: J. Sears \& P.J. Bacon (eds.), Proc. 3rd Int. Swan Symp., Oxford, 1989. Wildfowl (Special supplement no.1).

Copp, J. D. [1989]. Results of the 1987 survey of waterfowl hunting on the Yukon-Kuskokwim Delta, Alaska. Oregon State Univ., Corvallis, Oreg. Unpubl. Rept. 40 pp + appendices.

Forbush, E. H. 1912. A history of the game birds, wildfowl, and shore birds of Massachusetts and adjacent States. Massachusetts State Board of Agriculture. 622pp.

Munro, M. E. 1981. Traditional return of Cygnus columbianus columbianus to wintering areas in 
Maryland's Chesapeake Bay. Pp. $81-98$ In: G. V. T. Matthews \& M. Smart, (eds.), Proc. 2nd Int. Swan Symp., Sapporo, 1980. IWRB, Slimbridge.

Schroeder, L. (Chmn.) 1983. Pacific Flyway management plan for the western population of Whistling Swans. Subcommittee on Whistling Swans, Pacific Flyway Study Committee, Portland, Oregon. Unpubl. Rept. $27 \mathrm{pp}$.

Serie, J. R. \& Bartonek, J. C. 1991. Population status and productivity of Tundra Swans, Cygnus columbianus, in North America. In: J. Sears \& P. J. Bacon, (eds.), Proc. 3rd Int. Swan Symp., Oxford, 1989. Wildfowl (Special Supplement no.1).

Sherwood, G. A. 1960. The Whistling Swan in the west with particular teference to Great Salt Lake Valley, Utah. The Condor 62(5):370-377.

USDI. 1984. Environmental Assessment: Proposed hunting regulations on eastern population of Whistling(Tundra) Swans,1984 USFWS, Unpubl. Rept. 11 pp.

Jerome R. Serie, Atlantic Flyway Representative, U.S. Fish and Wildlife Service, Laurel, Maryland. USA. James C. Bartonek, Pacific Flyway Representative, U.S. Fish and Wildlife Service, Portland, Oregon. USA. 